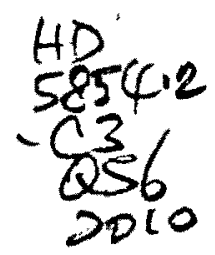

\title{
PLUNGING INTO PRECARIOUS WORK: NEOLIBERALISM, IMMIGRANT LABOUR AND THE CASE OF BATHROOM ATTENDANTS IN TORONTO, THE "GLOBAL CITY"
}

\author{
by
}

Mariana Quintero, BA, University of Toronto, 2009

\author{
A Major Research Paper \\ presented to Ryerson University \\ in partial fulfillment of the requirements for the degree of \\ Master of Arts \\ in the Program of \\ Immigration and Settlement Studies
}

Toronto, Ontario, Canada, 2010

C Mariana Quintero 2010 


\section{Author's Declaration}

I hereby declare that I am the sole author of this major research paper.

I authorize Ryerson University to lend this paper to other institutions or individuals for the purpose of scholarly research.

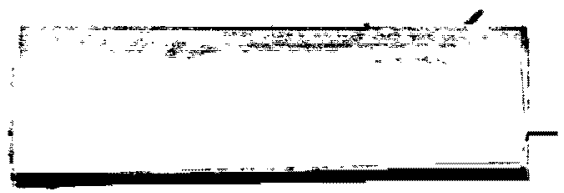

I further authorize Ryerson University to reproduce this paper by photocopying or by other means, in total or in part, at the request of other institutions or individuals for the purpose of scholarly research.

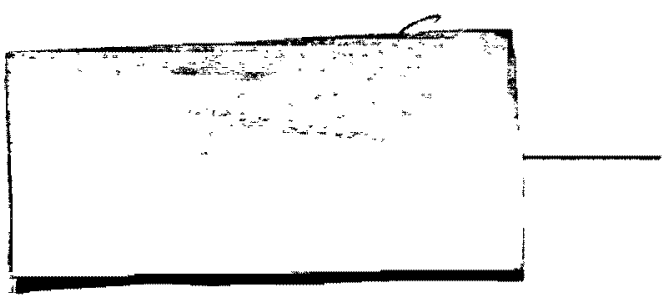




\title{
PLUNGING INTO PRECARIOUS WORK: NEOLIBERALISM, IMMIGRANT LABOUR AND THE CASE OF BATHROOM ATTENDANTS IN TORONTO, THE "GLOBAL CITY"
}

\author{
Mariana Quintero \\ Master of Arts, 2010 \\ Immigration and Settlement Studies \\ Ryerson University
}

\section{ABSTRACT}

This paper builds on Canadian research documenting immigrants' overrepresentation in 'precarious work', and the manifestations of poor working conditions in their daily lives. To do so the paper presents a two-fold analysis. The first section critically analyzes how the 'global city' and neoliberal restructuring reinforce structural and ideological barriers limiting immigrants from decent work and pushing them to precarious work. The second section introduces the case study of bathroom attendants working in Toronto's nightclubs. It contributes to the literature by documenting the organization of work and analyzing how the indicators of precarity pertain to this position. The research finds that bathroom attendants experience precarity because of their location in the informal sector and the nightclub industry, in addition to their work arrangements and social location as immigrants. It concludes by documenting tactics of resistance deployed by these workers to contest their social powerlessness.

Key words: Bathroom attendants, immigrants, precarious work, informal work, labour market, Global City, Canada. 
"LA VIDA NO ES COMO UNO LA VIVIO, SINO LA QUE UNO RECUERDA, Y COMO LA RECUERDA PARA CONTARLA"

“LIFE IS NOT WHAT ONE LIVED, BUTT WHAT ONE REMEMBERS

AND HOW ONE REMEMBERS, IN ORDER TO RECOUNT IT"

Gabriel Garcia Marquez

The following pages are my testimony of gratitude towards everyone who helped me live this year. I hope some day we are able to remember and recount this story together. 
Table of Contents

INTRODUCTION

IMMIGRANT LABOUR IN THE GLOBAL CITY 4

Conceptualizing Precarious Work: From a Dichotomy to a ContinuUm 4

RELATIONSHIP BETWEEN IMMIGRATION STATUS AND PRECARIOUS WORK IN CANADA 5

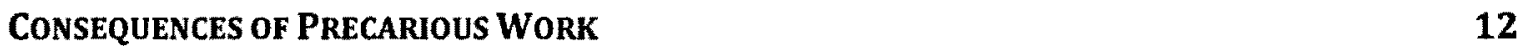

EACTORS LEADING IMMIGRANTS TO PRECARIOUS WORK

StruCtural CONDITIONS OF THE LABOUR MARKET

Policies of SOcial EXClusion: Neoliberalism and THE Growth OF THE "CREATIVE Class" 17

CASE STUDY: TORONTO'S BATHROOM ATTENDANTS 23

CONSUMPTION IN THE 'ENTERTAINMENT DISTRICT': LOCATING BATHROOM ATTENDANTS 23

RESEARCH METHOD $\quad 25$

Characteristics OF THE SAMPLE POPULATION

ORGANIZATION OF WORK $\quad 30$

JOB DESCRIPTION

RECRUITMENT AND CONTRACTS $\quad \mathbf{3 4}$

INDICATORS OF PRECARITY FOR BATHROOM ATTENDANTS

EMPLOYMENT CERTAINTY $\quad 39$

CONTROL OVER THE LABOUR Process $\quad \mathbf{4 0}$

EARNING UNCERTAINTY

REGULATORY PROTECTION $\quad-\quad 48$

THE COSTS OE EMOTIONAL LABOUR

TACTICS OF RESISTANCE $\quad 54$

CONCLUSION $\quad 56$

AREAS FOR FURTHER RESEARCH

\begin{tabular}{ll} 
WORKS CITED & 61 \\
\hline
\end{tabular}

APPENDIX $\quad 65$

APPENDIX A: INTERVIEW QUESTIONS $\quad 65$

LIST OF TABLES

TABLE 1: INDICATORS OF PRECARIOUS WORK 5

TABLE 2: PARTICIPANTS' DEMOGRAPHICS $\quad 29$

TABLE 3: BATHROOM ATTENDANT RESPONSIBILITIES AND TASKS 33

TABLE 4: INDICATORS OF PRECARITY FOR BATHROOM ATTENDANTS IN TORONTO'S
NIGHTCLUBS 


\section{Introduction}

Poor labour market integration of immigrants has become an increasingly serious problem in the past three decades (Galabuzi, 2006; Shields, 2004, pp. 29-33; Walters, Phythian, \& Anisef, 2006). For both unskilled and skilled immigrants, the inability to find stable employment pushes them to the margins of the labour market, to positions and work contracts that create conditions of vulnerability and involve "precarious work" (Bauder, 2006; Goldring \& Landolt, 2009). The consequences of precarious work spill over to other spheres of a person's life and can negatively alter the well being of the employee and his or her dependents(Immigrants' economic vulnerability, combined with unfavorable working conditions, has a direct effect on their physical and mental health, political and social integration and quality of life (Galabuzi, 2006; Lewchuk, Wolff, King, \& Polanyi, 2006; Shields, 2004)/

In Canada since the 1980 s, statistics on immigrants' labour market integration reveal a decline in immigrants' labour market performance (Walters, et al., 2006). In the last few decades, there is a decrease in 'middle class jobs' ${ }^{1}$ as a direct result of economic restructuring, deregulation of labour laws and standards, decline in unionization and the consequent polarization of the labour market. Under these conditions, only a quarter of legal immigrants are able to secure middle class jobs. However, this group represents the exception, while the remaining immigrants are pushed to the bottom of the labour market where precarious work prevails (Shields, 2004).

\footnotetext{
${ }^{1}$ For the purpose of this analysis 'middle class jobs' are defined as jobs that provide employees with some degree of security, stability, control over their work, social and legal protection. These jobs are regulated by labour laws and/or through union protections and they provide a fair income to employees. "Middle class jobs" might not necessarily exhibit all of the above conditions but they still offer relatively decent working conditions in comparison to precarious work which lacks most (if not all) of the conditions previously mentioned.
} 
Precarious work is understood as work that is unstable and insecure, offers limited rights, benefits and protection to the worker. It allows workers little control over their schedule and the production process (Evans \& Gibb, 2009; Goldring, Berinstein, \& Bernhard, 2007; Goldring \& Landolt, 2009; Vosko, 2006). Canadian research has indirectly looked at immigrants' experience in precarious work through a focus on race, and gender. However, there has been little research that focuses directly on the intersection of immigration and precarious work. There is a need for studies documenting different experiences and effects of precarious work on newcomers and Canadian born people (Goldring \& Landolt, 2009). This study helps address this gap in the literature as it exposes the structural and ideological barriers limiting immigrants from accessing decent work. The study focuses specifically on immigrants working as bathroom attendants in the entertainment district in Toronto.

Theoretically this paper is rooted in a new political economy framework. Unlike Itraditional political economy, which focuses on how political and economical structures shape decision making, the new political economy recognized that society too has an impact/(Sayer, 2001). As a neo-Marxist approach, the new political economy exposes how segregation of immigrants in the labour market is a result of political, economical and social forces. This critical approach helps focus research on hegemonic ideologies, policies and regulations, intertwined in everyday life, marginalizing immigrants and pushing them into highly exploitative working conditions. Thus, one of the primary goals of this thesis is to expose the reflexive relationship that exists between the structural and the ideological.

There is a tendency in political economy to view immigrants and other $\frac{1}{40}$ marginalized workers as victims./As such, this approach generally fails to recognize the 
agency of those subordinated in capitalist relations. To counter this weakness, I have chosen to conduct open-ended interviews with bathroom attendants working in Toronto's entertainment industry. In line with a post-modernist rejection of objective truth and universalistic and global narratives, open-ended interviews allow the reader to see the agency and strategies of contestation as they are practiced by workers in their everyday life.

The analysis in this study is two-fold. The first section reviews the literature documenting immigrant labour in global cities like Toronto, looking at the intersection of immigration status (as a social location) and precarious work. This strategy exposes how newcomers are fairing in today's global economy, and the consequences of their work. In addition to the literature review, this study explores the causes that lead to immigrants' overrepresentation in 'bad jobs' by looking at the implication of neoliberal policies and structural changes to the labour market. The second section is based on a case study of bathroom attendants working in Toronto's nightclubs. There is an overrepresentation of immigrants in this position, with work arrangements that are informal and highly precarious. The case study will exemplify patterns and trends discussed in section one. The case study contributes to the literature by not only documenting the experiences and indicators of precarity present in this occupation, but also by giving voice to the immigrants and visibility to their daily struggles. 


\section{Immigrant Labour in the Global City}

\section{Conceptualizing Precarious Work: From a Dichotomy to a Continuum}

Canadian research on precarious work defines it as an "atypical employment contract, with limited social benefits and statutory entitlements, job insecurity, low job tenure, low wages and high risks of ill health" (Vosko, 2006, p. 1). The majority of workers employed under these conditions are made vulnerable by numerous constraints that restrict them from challenging employers, working conditions and seeking better work (Bauder, 2006; Goldring \& Landolt, 2009). Immigrants are sometimes considered to be a valuable addition to Canada's labour market precisely because their vulnerability is entrenched in their status as immigrants (Bauder, 2006). Unfortunately, precarious jobs reinforce and aggravate immigrants' vulnerability, rendering them captive to precarious work in the long term. /

Precarious work is not a homogenous category. Literature documenting precarious employment recognizes a small group of workers who may choose "autonomy, risk and greater potential rewards over the routine and security of full-time, permanent jobs" (Evans \& Gibb, 2009, p. 15). These workers are predominantly male and well educated, they choose contract work for the flexibility and autonomy it offers (Evans \& Gibb, 2009). Multiple short-term contracts allow them to acquire a variety of attractive skills and knowledge that make them employable and competitive in the labour market. They differ from the majority of precarious workers because they are able to transition from contract work to full time permanent position (Vosko, 2006). In developing a general understanding of precarious work, noting the distinction between this privileged group and the majority of precarious workers is important. The success of this small group, however, is an exception and it will not be the focus of this analysis. 
Understanding different manifestations of precarious work requires that we deviate from a 'good job' 'bad job' dichotomy to a more encompassing 'continuum of precarity'. Adopting a continuum allows us to recognize that what makes workers vulnerable might involve many other elements besides the employment contract (Evans \& Gibb, 2009; Goldring \& Landolt, 2009; Lewchuk, et al., 2006; Vosko, 2003). New Canadian research attempts to document and understand a variety of indicators, which in isolation may not signal precarity, but collectively create conditions of precarity (See table one). Focusing on indicators such as degree of employment certainty, control over the labour process, income certainty and regulatory protection, allows researchers to make comparisons between sectors and specific jobs.

TABLE 1: INDICATORS OF PRECARIOUS WORK

\begin{tabular}{|l|l|}
\hline $\begin{array}{l}\text { Employment } \\
\text { Certainty }\end{array}$ & $: \begin{array}{l}\text { Predictability of future employment } \\
\text { Tied to employment and contract details }\end{array}$ \\
\hline $\begin{array}{l}\text { Control Over the } \\
\text { Labour Process }\end{array}$ & $\begin{array}{l}\text { Greatly influenced by Unions, and contract type } \\
\text { Lack of control over working conditions, wages and work } \\
\text { intensity }\end{array}$ \\
\hline Income certainty & $\begin{array}{l}\text { Income insufficient to maintain worker and dependents } \\
\text { Influenced by number of dependents and household income }\end{array}$ \\
\hline $\begin{array}{l}\text { Regulatory } \\
\text { Protection } \\
\text { and control }\end{array}$ & $\begin{array}{l}\text { Degree of protection through union representation or } \\
\text { provincial and federal law }\end{array}$ \\
\hline
\end{tabular}

Source: (Vosko, 2006, pp. 29-33)

\section{Relationship Between Immigration Status and Precarious Work in Canada}

Canadian Literature links precarious employment to the social location of individuals such as gender, race, occupation and immigration status (Cranford \& Vosko, 2006; Goldring \& Landolt, 2009). Immigrant status as a social location, however, has not 
yet been sufficiently explored in relation to precarious work(Goldring \& Landolt, 2009). Immigrants have been studied only indirectly by research that looks at how race and gender play a role in labour market segregation. Immigration is making Canada's population distribution ethnically and racially diverse ${ }^{2}$, thus implicitly adding a racial dimension to immigration studies (de Wolff, 2006; Galabuzi, 2006; Teelucksingh \& Galabuzi, 2007). Studies thus far have documented the over-representation of immigrants in precarious work however a more direct focus on immigration status is necessary if we wish to understand the rationale behind these trends. The following section reviews trends and statistical analyses that map the experiences of immigrants in Canadian low-income sectors as well as precarious work.

In a traditional gender division women have been assigned to the work of social reproduction which involves tasks necessary to "reconstitute classes and conditions of work from day to day and generation to generation" (Collins \& Gimenez, 1990, p. 4). The absence of economic remuneration for these tasks has been justified by their conceptualization as a "natural" outcome of women's caring and nurturing nature. Men, on the other hand, have enjoyed more stable, prestigious and economically remunerating positions outside the home and recognized as the "real" workers in a capitalist economy. Although many women have chosen or been forced by economic conditions to work outside the home their work continues to be undervalued. Women are overrepresented in low-paid and high-risk forms of employment that are part-time permanent and part-time temporary. Immigrant women of colour experience double

\footnotetext{
${ }^{2}$ Changes to immigration policy in 1967 led to the adoption of the 'point system', which awards applicants points based on human capital. This has resulted in the diversification of Canada's ethnic and racial makeup by admitting immigrants from non-traditional countries.
} 
oppression for their gender and 'race's, and consequently are more likely to be permanently part-time employees than their male counterparts (Vosko, 2006, p. 59).

Labour market insecurity in Canada is strongly connected to a racialized gendering of jobs. The term 'gendeting of jobs' is intended to describe the decline in quality of jobs "to resemble work associated with women and other marginalized groups" (Vosko, 2006, p. 64). Men are increasingly experiencing a decline in the traditional levels of security, which make their work as vulnerable as women's (Galabuzi, 2006; Vosko, 2006). Men of colour are 'slightly more likely than white men to be in the more precarious part-time temporary and part-time permanent forms of employment" (Vosko, 2006, p. 59). The downward pressure experienced by men of colour constitutes part of a labour hierarchy, one in which white men experience the most employment security while women of colour particularly immigrants, are most vulnerable.

In addition to race and gender, immigration status as a social location also has important implications for one's labour market participation, earnings and likelihood of participation in precarious employment. Newcomers that enter Canada without permanent residency are increasingly found in precarious work (Goldring, et al., 2007; Goldring \& Landolt, 2009). This is in part due to the prejudices held by employers who are unwilling to hire workers with temporary work permits(Goldring, et al., 2007). Even when newcomers who enter with temporary visas or work permits make a transition to permanent residency status, the precarity of their employment does not necessarily change. Thus, immigrants' status upon arrival plays an important role not just in the type of work they can access in the short term, but it can also impact their future work

${ }^{3}$ This is commonly referred to as the 'double negative effect'. 
(Goldring \& Landolt, 2009). Immigrants entering under the 'economic class' and with permanent residency status are prone to fall victims to "occupational mismatch"4 (Galabuzi, 2005). Longitudinal studies estimate that $32 \%$ of new immigrants between 2004-2006 found employment in their field of expertise in the first year of residency and only $9 \%$ in their second year (King, 2009, p. 28). After 3 years of residency, $90 \%$ of immigrants not employed in their field of expertise do not return to their trained occupation resulting in 'occupational mismatch' (Galabuzi, 2005, p. 56):

Statistics reveal that recent immigrants settling in urban Canada experience a steep earning gap (Bauder, 2006; Galabuzi, 2005; King, 2009; Shields, 2004). In 2005 immigrants with post secondary education earned $75.5 \%$ of the income of those with the same level of education born in Canada. Earning gaps are larger (70.9\%) in the main immigrant receiving provinces, such as Ontario, Alberta, Quebec and British Columbia. In Ontario this gap translates to a difference of $\$ 20,740.00$ annually (King, 2009, p. 2). Earning gaps also exist between different immigrant cohorts. Recently arrived immigrants earn considerably less than those who came between 1990 and 1995. The 1990s cohort also report lower earning rates than those who arrived in the 1980s (King, 2009). This trend is alarming as recent cohorts possess even higher educational achievements and more work experience in their fields compared to previous cohorts of immigrants. These findings reveal how recent immigrants are challenged by the deterioration of their wages and the devaluation of their human capital.

${ }^{4}$ Occupational mismatch is a term used in the literature to explain how individuals with specific education and training are unable to find work in their fields, consequently they are forced to find employment in other occupations. 
The economic recession of 2008 has negatively affected labour market participation of immigrants in Canada. In 2010 only $73.3 \%$ of recent immigrants in Canada were participating in the labour market compared to $83.5 \%$ of previous cohorts of immigrants and $87.9 \%$ of those bórn in Canada (Kelly \& Lemoine, 2010, p. 6). It is important to note that 'participation' alone does not provide any insight into the quality or stability of jobs immigrants have. In other words, some of the jobs measured by this statistic may be precarious in nature. In May of 2010 the unemployment rate of immigrants in Toronto's CMA was $11 \%$ compared to $6 \%$ for the Canadian born. Immigrants' unemployment rate has jumped almost 5\% from November 2008 while that for the Canadian born it has risen less than $2 \%$ during the same time (Kelly \& Lemoine, 2010, p. 7). These trends display the volatile place of immigrants' in Canada's labour market, and show how drastically they are impacted by economical instability. Being at the margins of the market results in low incomes, and disproportionate exposure to unstable, insecure and informal work (Carr \& Chen, 2002; Chen, 2004; Sassen, 1994).

Comparing occupations and sectors reveals that occupations in the sales and service sectors are amongst the most precarious jobs. The service sector, which accounts for $40.4 \%$ of Ontario's labour force, is characterized by lack of unionization, absence of a social wage ${ }^{5}$ and incomes that fall below the poverty line ${ }^{6}$. Ontario's lowwage service workers earned an annual income of $\$ 37,700$ in 2006 . This figure, however, only includes full time workers, meaning that part-time work in this sector

\footnotetext{
${ }^{5}$ A social wage refers to a package of benefits such as extended eye and dental care, pensions and life insurance, which lowers the vulnerability improves the standard of living of individuals and their dependents (Vosko, 2006).

${ }^{6}$ As defined by Statistics Canada, families or individual living below this income level are

- considered to be living in 'straitened circumstances'. For more information see http://www.cesd.ca/factsheets/fs lico04 bt.htm
} 
falls below this already low figure (Verma, 2009, p. 11). Low- wage service work has a 'sizeable' proportion of immigrant workers many of whom are concentrated in clerical and health related jobs, as well as technical occupations in health, childcare and home care. Of these clusters approximately $28 \%$ of these positions are filled by immigrants who earn $\$ 15.63 / \mathrm{hr}$, yet only $54 \%$ of them are full time ${ }^{7}$ (Verma, 2009, p. 24). Because low-wage immigrant workers not only earn significantly less than other occupations but also work fewer hours, this pattern restricts their access to a decent living income, forcing people to seek multiple jobs.

Often overlooked, self-employment is increasingly becoming an immigrantdominated sector, particularly in the personal services sector (Pennington, 2009). Immigrants excluded from the labour market due to lack of credential recognition, Canadian experience, racism and discrimination choose self-employment or entrepreneurship as a viable way to earn a living wage. These groups are erroneously perceived as economically independent, autonomous, and not needing labour protection. In reality, these immigrants face a high level of vulnerability in great part due to their inability to secure long-term work, lack of a social wage, lack of labour regulation by the state and exposure to a competitive work environment (Fudge, 2003). 'Independent contractors' and 'self employed' are all categories that must be contextualized in the reality of today's labour market. These jobs are no longer necessarily a sign of prestige but often the last resort for immigrants to earn a living by selling their labour in the market.

Canada's informal sector is understudied. Attempts to expose connections between informality, precarious work and immigrants are hampered by lack of

\footnotetext{
${ }^{7}$ In this study full- time refers to anyone working forty hours or more per week.
} 
sufficient data. Studies of informal economies in other developed economies ${ }^{8}$ report overrepresentation of racialized low skilled immigrants in what are highly precarious jobs (Carr \& Chen, 2002; Chen, 2004; Sassen, 1994). Newcomers at the margins or with uncertain immigration status are more prone to participating in informal work, particularly in urban centers where the job market is more competitive and less hospitable to newcomers (Sassen, 1994; Shields, 2004). For these reasons it would not be unreasonable to expect that out of approximately $250,000^{9}$ immigrants admitted into Canada annually, many of them would be pushed to informal and semi-informal work (King, 2009). Women and visual minorities are more inclined to end-up in the informal sector. In this way, this sector reproduces the gender and racial inequalities already present in Canada's labour market (Carr \& Chen, 2002; Chen, 2004). Informal jobs display many indicators of precariousness. As they escape the protection and regulations of the state, they often lack permanence and stability, and earning are lower than stipulated by the province. The general conditions of precariousness along with the individual factors of social location can make immigrants in informal work the most vulnerable and defenseless worker in the labour market hierarchy.

Toronto is one of Canada's most important cities for financial development and attracting foreign investors. Unfortunately, these features have also made the labour market in this region unwelcoming towards immigrants, many of whom are over exposed to precarious jobs, poverty and social exclusion. Approximately fifty percent of Toronto's 2.6 million populations are foreign born. In addition, the city becomes home to about 100,000 newcomers every year (King, 2009). The challenges recent

\footnotetext{
${ }^{8} \mathrm{~A}$ large quantity of literature in the U.S.A documents this pattern, as well as Australia and England. See (Chen 2004, Carr and Chen 2002)

${ }^{9}$ This figure excludes temporary foreign workers as the majority of these workers enter Canada to complete precarious work that otherwise would not be filled.
} 
immigrants face when accessing decent work, are exacerbated in the competitive urban landscape. Immigrants in Toronto experience higher unemployment rates, more precarious jobs, double digit income gaps, and occupational mismatch (Kelly, 2010). This bleakness of urban economic circuits is a result of structural and policy changes in the new global economy. The growth of the service sector in Ontario, shifts to privatization and the wearing away of the public sector has resulted in the disappearance of stable full time jobs. Under these conditions jobs available to newcomers are usually in the service industry which is economically less stable and offers few hours. These low-wage, unstable jobs report having a 40 to $60 \%$ rate of visual minorities workers depending on the industry (Verma, 2009, p. 24), highlighting trends towards the racialization of poverty ${ }^{10}$. Lastly the growth of informal work is also a feature of large competitive urban centers (Sassen, 2006).

\section{Consequences of Precarious Work}

Precarious work has acute consequences for immigrants and their family units. A large body of literature documents the declining physical and mental health of precarious workers (Galabuzi, 2006; Goldring \& Landolt, 2009; Lewchuk, de Wolff, King, \& Polanyi, 2003; Lewchuk, et al., 2006; Pennington, 2009). Workers that lack control over their work environments, hours of work, work procedures and workload are more prone to suffer from "job strain". "Job strain" describes work related stress, which leads to "exhaustion, depression, job dissatisfaction and stress related illnesses such as

\footnotetext{
${ }^{10}$ The racialization of poverty defines the concentration of poverty among racial minorities as a result of socio-economic features that conspire with racism and discrimination. The result is the economic and social exclusion of these individuals and possibly future generations (Galabuzi 2005).
} 
cardiovascular disease." (Lewchuk, et al., 2006, p. 457). Precarious workers are at higher risk of work related injuries or illnesses, which often go untreated because of lack of benefits, sick pay, or the near impossibility of taking time off (Lewchuk, et al., 2003). In this way it is the bodies of precarious workers as instruments of labour that must adapt to the accelerated pace of production to ensure future employability, although this may translate to physical illnesses (Harvey, 2000, p. 117). The state under neoliberalism no longer claims "responsibility for maintaining and rehabilitating the sick..." bodies of workers. Instead, this responsibility is relegated to the individual. Flexible contracts allow employers to dispose and easily replace those bodies that become worn out through their labour (A. Aguiar, 2006b, p. 531).

Because, "attachment to the labour market is essential to both livelihood and production of identity in society" (Galabuzi, 2006, p. 183), immigrants failing to achieve economic integration"11 experience "social exclusion". "Social exclusion" is understood as unequal access to social economic, political and cultural resources achieved by structural processes in society. Newcomers' ethnicity, race, and immigration status become the basis that allow inequalities to persist (Galabuzi, 2006). Labour market segregation, stagnant upward mobility, employment discrimination and unemployment are all factors influencing the economic exclusion of many Canadian immigrants. The consequences of social exclusion are vast. According to Galabuzi, they extend from limited social participation to overexposure to the criminal justice system; from limited health care to neighborhood segregation and feelings of despair and depression. Socially excluded members of society have to struggle with a reality that extends

\footnotetext{
11 Integration is defined as the ability of newcomers to achieve income parity with newcomers when controlling for human capital, and work experience (Shields, 2004).
} 
beyond absence of material needs to a receding sense of belonging, and dignity that inevitably affects dependents and family members (Galabuzi, 2006).

Immigrants' low incomes have detrimental consequences on their livelihood by increasing their chances to fall below the poverty line. Although working precariously is not the same as living in poverty, overrepresentation of recent immigrants and radicalized groups in precarious work has generally resulted in their exposure to poverty (Goldring \& Landolt, 2009). Double digit income gaps, unemployment, and underemployment rates are some of the social indicators that highlight the economic exclusion of recent immigrants and racialized groups in Canada. Earnings are essential to quality of life, as they affect access to quality of food, health care, education, and housing. Low incomes also affect a variety of family decisions, such as whether or not to have children, or to pursue education. It also limits the ability to save money for unexpected life circumstances (Evans \& Gibb, 2009; Lewchuk, et al., 2006). On a less conspicuous way, low incomes negatively.affect access to resources that structurally enable full membership and participation in Canadian society. Overall, low incomes render immigrants vulnerable as workers and as citizens (Arat-Koc, 1999; Galabuzi, 2006; Shields, 2004). 


\section{Factors Leading Immigrants to Precarious Work}

\section{Structural Conditions of the Labour Market}

Globalization, accompanied by policies that promote the 'competitiveness' of the economy, has had a drastic effect on the urban labour market; a shift in the responsibility of the state; and changes in the consumption and production practices in Canadian cities. These changes have directly effected the growth of precarious work and the economic and social exclusion of immigrants. The following section presents arguments from a variety of literatures that expose the structural processes that create the 'need' for low paid, low skill labour and the state's actions that make immigrants vulnerable and therefore more prone to engage in these types of jobs.

The global economy is the geographical reorganization of a multiplicity of spaces that come together to ensure the proliferation of capitalism. Globalization is the new phase in the history of capitalism (Harvey, 2000), and therefore is rooted in the competitiveness that ensures the largest profit margin (usually) through lower production costs (Sassen, 2006). These costs do not just vanish; they are absorbed by workers and the families of workers at the end of production circuits, through reduced pay, lack of benefits, and their poor physical and mental health. In this system the 'competitiveness of the market' is used to justify "restructuring and policies of economic development, finance, taxation, land use planning, urban design, 'culture,' diversity management, policing and workfare" (Kipfer \& Keil, 2002, p. 235). This new phase of capitalism also re-enforces racist, classist and sexist ideologies to justify social organization and the division of labour. The histories of these hegemonic ideologies are intertwined with the history of capitalism, as they have served to rationalize the 
"differentiation and subordination of people on the basis of superficial physical characteristics..." (Das Gupta, 1996, p. 9).

"Global cities" work as management centers for the global economic system. They compete to attract foreign investors, global corporations and their high-income highly skilled workforce (Cervenan, 2009; Sassen, 2006) Canada is no exception to the way global cities work, with the three main levels of government (federal, provincial, municipal) aggressively pursuing a global city agenda . Establishing global cities allows governments to regain influence over the economic system, as well as capital to fuel their political agenda (Sassen, 2006). In Canada, increasing competitiveness has translated to open markets, privatization, deregulation and policies that facilitate capital accumulation for investors and corporations. In Toronto, immigration is central to the marketing of the city as an attractive investment site both by creating a cheap and flexible labour force and by allowing the city to brand itself as a culturally diverse and tolerant place (Kipfer \& Keil, 2002, p. 164).

At a local scale the employee and employer relationships are also affected by the competitiveness of the global market. To reduce labour costs, employers employ tactics that deviate from the standard employment relationship, and in doing so they erode and break the laws that protect workers (Goldring \& Landolt, 2009). Some of the most disadvantageous working conditions result from informal work. This is because these jobs exhibit most of the precarious indicators and provide employees with weak or no labour or social protections. Employers and businesses that choose informal or semiinformal work do so because it grants them access to flexible specialized production, reduces labour costs and allows them to avoid their formal obligations to employees and the state In these circumstances it is the employer that chooses to break or erode 
employment standards and enjoys the benefits (Carr \& Chen, 2002). The need to remain competitive pushes more employers to adopt such tactics, leaving workers with less opportunities to access decent work (Goldring \& Landolt, 2009).

\section{Policies of Social Exclusion: NeoLiberalism and the Growth of the "Creative Class"}

Neoliberalism is a market driven approach to economic and social policy which attempts to minimize the state's regulatory presence as a way to promote quick capital accumulation (Shields, 2004). The introduction of neoliberal economic and social policies in Canada has meant opening domestic markets, signing free trade agreements, enticing foreign investors, privatizing important services and industries and deregulating labour laws (Kipfer \& Keil, 2002; Pennington, 2009; Sassen, 2006). For the development of the following argument it is also important to understand that neoliberalism promotes the application of market language and logic to all realms of life (Arat-Koc, 1999; Kipfer \& Keil, 2002). This has led to a new concept of citizenship, one that only assigns rights to labour market participants and promotes autonomy, and efficiency (Shields, 2004). Overall, neoliberalism has had effects on conceptualization of and practices in political, social and cultural dimensions of life.

Under neoliberalism the state no longer promotes policies that attempt to manage the economic polarity that is inevitably linked to open markets. Immigration, labour and social policies put forward by Canada's government in more than two decades of neoliberalism pose monumental challenges to the labour market integration of newcomers. Neoliberalism has not only distorted the role of the state and its responsibilities towards immigrants, but it has also contributed to the commodification of their labour through a hegemonic discourse of market competitiveness. 
Neoliberals subscribe to the idea that the state "has become too large and too interventionist within the economy and society" [Shields, 2004, p. 3). Their solution is to minimize the influence of the state by downsizing and privatizing so that responsibilities that traditionally belonged to the state are downloaded to the private sector and the family unit. In the mid 1990s the welfare state was restructured. As a result immigrant settlement programs experienced drastic funding cutbacks. These programs were the primary safety-net for new immigrants and families establishing themselves by providing training programs and the economic means necessary to build up skills to compete in the capitalist marketplace (Shields, 2004). What follows is a brief discussion of some of the policy changes which had the most detrimental results for immigrants.

In 1996 the "Employment Insurance Act" transferred delivery of employment services to non-governmental organizations. This move affected services like employment counseling and assessments, job search assistance and access to skill training (de Wolff, 2006). Reduction in the number of eligible Employment Insurance (EI) applicants was achieved by tighter eligibility rules. Immigrants, as new entrants to the workforce, must accumulate at least 910 hours of work in a 12-month period (de Wolff, 2006, p. 187). This is clearly a difficult task for a newcomer struggling to find decent employment in what is already an economically polarized and discriminatory labour market. Through the new eligibility requirements, immigrants are effectively excluded from El benefits and funded training programs (Shields, 2004). This is most unfavorable for women and racialized immigrants who find themselves at the bottom of the labour hierarchy. In this way these groups are distanced from the possibility of 
acquiring human capital that would otherwise allow them to escape the perpetual cycle of precarious work.

'Ontario Works' is Ontario's current workfare program funded by Human Resources and Skills Development Canada (HRSDC). Programs like "Ontario Works" and settlement services offered to immigrants through Citizenship and Immigration Canada (CIC) are systematically encouraging precarious work (de Wolff, 2006). These programs are designed to push immigrants into work --not necessarily into work they want or work appropriate to their skills-- in the shortest and most cost- efficient way possible. Assessment centers are expected to help $65 \%$ to $80 \%$ of their clients find work during their contract period. For those applicants completing individual action plans, they must report $80 \%$ success rate within three months of çompletion. These same targets are applied to immigrant serving programs (de Wolff, 2006, p. 192). Whether the job is stable and secure is irrelevant to the agency, the goal is to meet their quotas and therefore secure future funding. Immigrants limited by short-term programs, are pressured to accept employment that exhibits some dimension of precariousness. In this way the programs claiming to assist immigrants are in fact "undermining the idea of full-time stable work as a norm, and promoting the expansion of contingent work" (Vosko, 2000, p. 230).

Under neoliberalism the citizens are commodified for their labour and access to social rights has become contingent on labour market "participation". In Canada the welfare state serves as one of the most important structures guarding the social rights of citizens by providing social insurance and social assistance programs. Under neoliberalism qualifying for these benefits is contingent on proving labour market participation in wage work. Excluded from benefits are many self-employed, informal 
economy workers as well as women whose contributions through reproductive work are not recognized. The limitations in access to services such as EI or educational training exclude non-wage workers while stigmatizing them and their contribution as insignificant, as is the case with many newcomers.

The two largest immigration categories, skilled workers and temporary foreign workers, are selected on their ability to work upon arrival. Access to welfare programs is not granted to workers with the most need, instead an 'investment' is made on those that have demonstrated their ability to 'produce' and those that will begin 'producing' the fastest. In this way the state clearly outlines the criteria of a desirable citizen as those that are adaptable, self sufficient and able to contribute through 'work' (Shields, 2004). However, the narrow view of what qualifies as 'work' makes invisible the contribution of (certain) members in society, such as women, racialized immigrants and the elderly. The result is undervaluing of their contributions to society and possible social exclusion (Arat-Koc, 1999; de Wolff, 2006; Galabuzi, 2006).

The social exclusion of precarious workers is made invisible by the hypervalorization of high-income professionals. This hyper-valorization is best demonstrated by Richard Florida's assertion that economic growth is led by the "creative class". Florida's work is extremely relevant in Ontario, and even more so after his move to the University of Toronto in 2007 because through his work at the Martin Prosperity Institute at the University of Toronto and personal consultations, his theory has infiltrated policy agendas and strategies for economic growth (Whyte, 2009).

Florida theorizes that creative knowledge and ideas are the key factors of production in the new knowledge intensive economy. It is the creativity, innovation and human capital of the 'creative class' that fosters the economic growth of a city, which in 
turn affects regional growth. The 'creative class' is an occupational grouping characterized by their high human capital, and ability to "create and have considerably more autonomy and flexibility" when compared to the "service class" (Florida, 2002, p. 9). Thus, cities that wish to remain competitive must become sites able to attract the 'creative class' by catering to their lifestyle and consumption needs (Florida, 2002).

Linking human capital to economic growth is part of an elitist discourse that underestimates the contribution of the 'service class'. In this theory, the 'service class' (many of whom are precarious workers) is employed to produce with low wages and little autonomy over their work (Florida, 2002). Most importantly the 'service class' exists to supply the needs of the 'creative class'. What is overlooked is how the work of the 'service class' creates the foundation of the global economy, by facilitating the performance of high-income professionals who would otherwise be unable to function without their morning coffee, dry-cleaning or the nannies that care for their children (Bauder, 2006; Broad, 2000; Sassen, 2006).

The idea that the 'creative-class' is the primary source of economic growth is being normalized in new discourses. This idea has generated a number of important criticisms that revolve around the social exclusion of the 'service class'. The undervalorization of the 'service class', largely constituted by recent newcomers, makes their work invisible. The invisibility adds to the de-valorization of their contributions manifested by their low wages and unhealthy working conditions. It also makes political mobilization of these workers (regardless of the sectors) more difficult (Peck, 2005). The emphasis on 'innovation', 'creativity', and 'global competitiveness' reduces any demand for social rights and better working conditions to an economic discourse. In other words, those compelled to point out the social inequality and injustice 
exacerbated by policies aimed at attracting the 'creative class', must frame their objection in an economic discourse. The 'creative-class' discourse hides the effects of neoliberal policies and " depoliticizes insecurity, inequality and vulnerability by downloading risk and responsibility to the lowest possible scales", the workers [Cervenan, 2009, p. 11]. 


\section{Case Study: Toronto's Bathroom Attendants}

\section{Consumption in the 'Entertainment District': Locating Bathroom Attendants}

Because Ontario's economy relies heavily on its service sector, economic competitiveness is achieved through 'place making', the commercialization of spaces that further encourage consumption of goods and services. To compete on a global scale these spaces must appeal to the lifestyle of middle to high-income urban citizen, globally mobile talent and tourists. Many of Toronto's "place making" strategies revolve around the commodification of its ethnic diversity. In this way immigration is used to sell the city. In a less conspicuous way immigrants are the labour force that deliver the services to support an elite lifestyle. The maintenance of places and services catering to the elite lifestyle for a low price undermine the wage and health standards of the province in many ways (Sassen, 1994).

The entertainment district is an eight square- block area located in the downtown core of Toronto. It houses over 100 restaurants, bars, and nightclubs, which can service up to 30,000 clients in one night (Purcell \& Graham, 2005, p. 133). The 'entertainment district'. evolved in the 1990s from the need to isolate the noise, drug and violence associated with this industry, to a specific locality. A designated geographical space ensures easier vigilance and simplifies the commercialization and branding of the venues. Like much of the downtown this 'district' has undergone gentrification and is now a "commodified 'global postmodern' space of new middle class sensibilities" (Kipfer \& Keil, 2002, p. 236). To meet those 'sensibilities', businesses in this area exclude the "poor and disenfranchised through subtle demarcations based 
around dress and style codes, interior design, drink prices and entry requirements" (Purcell \& Graham, 2005, p. 133). Through these measures they ensure the exclusion of those citizens that disrupt the commercial image of a clean, safe and secure space.

Toronto's nightclub scene offers a variety of venues catering to different music tastes and the perceived socio-economic and ethnic makeup of the clientele. Clubs playing techno or dance music attract a more 'upscale', late twenties to early thirties crowd. They are for the most part located in the 'entertainment district' (Purcell \& Graham, 2005, p. 144). Pop clubs are more evenly distributed in different areas of the city, and tend to attract a twenty-something ethnically diverse crowd. Salsa and Alternative clubs are located outside of the entertainment district but still in the downtown core. In general, the club culture facilitates and celebrates alcohol consumption and fosters an "ethic of aggressive hedonism and sexuality" (Purcell \& Graham, 2005)

All these clubs rely on the cheap and easily available immigrant labour to fulfill the jobs that ensure the nocturnal operation of these venues. Cleaning, stocking, delivery of products, and renovations are some of the tasks performed by immigrants at a cheap cost and as invisible to the clientele. It is here that we locate bathroom attendants as the subject of this paper's case study. Bathroom attendants ensure the cleanliness of the bathroom and the comfort of the clientele during business hours. To the best of my knowledge, there is so far no research that has documented the working conditions or experiences of bathroom attendants. For this reason, this case study is exploratory in nature. It documents the precarity of the position of bathroom attendants by utilizing the indicators of precarious work, (employment certainty, control over the labour process, earnings, and regulatory protection). It also questions 
and explores the consequences of precarious work on the emotional and physical health of these immigrants.

\section{Research Method}

Bathroom Attendants in Toronto are an invisible group; in fact, whenever I share my research interest with others, I must explain what exactly bathroom attendants do and what kind of venues they work in. Those that are aware of the position have not given much consideration to the working conditions or the overrepresentation of immigrants in this job. This was definitely my case until I had the opportunity to do the work myself. At the time that I started working as a bathroom attendant I was starting my second year in university, and the possibility of having a job during weekends only and having ample time for school appealed to me. I performed as a bathroom attendant for approximately eight months. During this period I worked at five different nightclubs. It was the echo of my own experiences and those of other attendants that motivated me to further explore the working conditions of bathroom attendants in this analysis.

Knowing that my personal narrative could never expose and represent the variety of circumstances and situations that make tending to the bathroom a precarious job influenced the way I designed this study. I chose to conduct one- on-one, semistructured interviews hoping that this qualitative approach would give participants the flexibility to share with me what they consider to be important aspects of their jobs. I also selected a qualitative method in an effort to capture the emotional and physical corrosion that comes with the position. After receiving the approval of the Ethics Board at Ryerson University, I conducted six interviews in different locations in Toronto, 
ensuring that the places were safe and convenient for the participants and myself. The interviews were scheduled to last approximately fifty minutes. Some were slightly less and others went over this time frame (see appendix $A$ for interview questions). It is worth mentioning that participants were open and willing to cooperate and some offered to help recruit other participants. Unfortunately, due to the extensive amount of time transcribing requires and the deadlines of my program, I settled for only six participants. Although my interviewees do not constitute a representative sample of bathroom attendants in Toronto, the findings from the interviews provide a worthwhile contribution to knowledge on a yet unexplored field.

Recruitment of the six participants was made possibly by my personal network and the "snowball sampling" I used. I relied on a personal contact I had working as a bathroom attendant to distribute flyers to potential participants. My six interviewees were self selected among those who saw the flyer. They contacted me if they wanted to join the study. 'Snowball sampling' was chosen as my recruiting strategy, firstly because it is best when studying minority, marginal or hidden populations (Del Balso \& Lewis, 2005). Second, following the ethical guidelines, I could not recruit in places of work as I had to minimize any possible risks for the participant. Under these conditions, informal networks became the most efficient strategy in finding participants. Participants wishing to collaborate with the research needed to meet the following three criteria: they had to be over the age of 19 ; self identify as immigrants; and currently working as a bathroom attendant in one of Toronto's night clubs. 
I found that stages of research and data gathering were made easier by my own social location. Being a 1.5 generation ${ }^{12}$ Latin American woman meant that I could culturally relate to my participants who were all Latin American themselves ${ }^{13}$. In addition, competency in Spanish facilitated the interview process as many of the participants had little knowledge of English or simply preferred their native tongue. I chose to be very open about my experience as a bathroom attendant and at times shared my own personal anecdotes. This personal revelation made our experience of work as bathroom attendants a point of commonality and it helped change the atmosphere of the interview to a more casual and relaxed one.

My gender and my age, as well as those of the participants, at times posed limits on the type of information that respondents offered. For example men were more willing to share information on the inner workings of the position, tasks and responsibilities and providing anecdotes on unusual events on the job. Women, on the other hand, were generally more expressive about the physical and emotional toll of the job on their bodies, individual psyche and on their families. These differences between female and male participants can be explained by the construction of gender roles in Latin America. Men assume a strong protectionist role (Stevens, 1973), thus discussing the emotional and physical consequences of the job with a younger woman could be interpreted as a revelation of their vulnerability, countering their masculinity. Women's reflections on the effects of the job on family dynamics, however, is perfectly in line with the construction of women as keepers and primary tenders of the home

\footnotetext{
121.5 generation refers to children who migrate during childhood or adolescence. This generation experiences different settlement differently from the first generation or the second generation.

${ }^{13}$ Some characteristics of the sample group such as region of origin and employer were influenced by the sampling strategy.
} 
(Stevens, 1973). Women's contributions to the study reflect their responsibilities within their family structures as dictated by the construction of their gender.

I was fortunate that the research process did not pose any major challenges either in the recruitment of the interviewees or during the interviews themselves. Finding participants was made easy with the cooperation of participants, my previous experience as a bathroom attendant and my position as a Latin American. Time however was a major obstacle to expanding my sample further as the approval of ethics was a time-consuming process and interviewing, transcription and analysis would require time, perseverance and discipline. Another significant challenge was producing the analysis in such way that the identity of the participants would remain concealed, to eliminate or minimize any risks participants might incur by taking part in this research.

With interviews and transcripts completed, I proceeded to analyze the data in a three-stage process. First, I searched the transcripts for the "indicators of precarious work"14, seeking to understand how the organization of work and the duties associated with the position were precarious. Second, I looked for shared experiences among participants and common themes emerging in the interviews. Here, I was specifically interested in discovering shared feelings and strategies to improve work conditions (if any). Third, I analyzed some of the anecdotes and personal stories to see how social location of the worker and the specific nature and conditions of this job conspire to make each worker vulnerable. The findings are presented in the following section.

${ }^{14}$ See table one and 'conceptualizing precarious work' in this analysis. 


\section{Characteristics of the Sample Population}

This research was made possible with the assistance of six bathroom attendants who willingly shared their anecdotes and experiences with me. In an effort to conceal their identity in what is a relatively small industry I have chosen not to include their country of birthplace or any specific identity markers in the analysis. Instead, I offer the reader the following table documenting some of the demographic data gathered during the interview process. Some entries are blank because it was information that the participant did not wish to share.

TABLE 2: PARTICIPANTS' DEMOGRAPHICS

\begin{tabular}{|c|c|c|c|c|c|c|c|}
\hline & Sex & $\begin{array}{c}\text { Age } \\
\text { Range }\end{array}$ & $\begin{array}{l}\text { Time as a } \\
\text { Bathroom } \\
\text { Attendant }\end{array}$ & $\begin{array}{l}\text { Years } \\
\text { Since } \\
\text { Migration } \\
\text { to Canada }\end{array}$ & $\begin{array}{c}\text { Number of } \\
\text { Jobs Held } \\
\text { at the } \\
\text { Present* }\end{array}$ & $\begin{array}{c}\text { Highest } \\
\text { level of } \\
\text { Education } \\
\text { attained** }\end{array}$ & $\begin{array}{l}\text { Immigration } \\
\text { and } \\
\text { Citizenship } \\
\text { Status*** }\end{array}$ \\
\hline $\begin{array}{c}\text { Participant } \\
1\end{array}$ & Female & $25-30$ & 1.5 & 2 & 2 & $\begin{array}{c}\text { High School- } \\
\wedge A\end{array}$ & $\mathrm{n} / \mathrm{a}$ \\
\hline $\begin{array}{c}\text { Participant } \\
2\end{array}$ & Female & $25-30$ & 1 & 8 & 2 & $\begin{array}{c}\text { College } \\
\text { Diploma }\end{array}$ & Citizenship \\
\hline $\begin{array}{c}\text { Participant } \\
3\end{array}$ & Male & $25-30$ & 2 & 9 & 2 & High School & Citizenship \\
\hline $\begin{array}{c}\text { Participant } \\
4\end{array}$ & Male & $30-35$ & 3 & 6 & 2 & Masters - ^A & $\begin{array}{l}\text { Permanent } \\
\text { Residency }\end{array}$ \\
\hline $\begin{array}{c}\text { Participant } \\
5\end{array}$ & Female & $35-40$ & 3.5 & 6 & 1 & $\begin{array}{c}\text { University- } \\
\wedge A\end{array}$ & $\begin{array}{l}\text { Permanent } \\
\text { Residency }\end{array}$ \\
\hline $\begin{array}{c}\text { Participant } \\
6\end{array}$ & Male & $55-60$ & 5.5 & 7 & 2 & College & $\mathrm{n} / \mathrm{a}$ \\
\hline
\end{tabular}

*Including part time or full time number of jobs at the time of the interview

**Educational attainment either in Canada or other countries

***There was no question on immigration or citizenship status in the interviews. Some participants volunteered this information.

${ }^{\wedge} \mathrm{A}$ Participants that were actively engaged in some form of education at the time of the interview 


\section{Organization of Work}

The "organization of work" is a broad term intended to describe how work is defined, designated and managed by looking at a variety of issues such as scheduling, job design, procedures, management style and communication strategies. As an analytical tool, it can be used at a macro level to understand how work is divided in society, or at a micro level to understand the organization of work in a specific industry, business or even the home (Vosko, 2006). By piecing together the descriptions of participants along with the previous work experiences of the researcher, the following section provides a job description for bathroom attendants and documents the hiring and managing practices employed in this business. It also documents how the work of bathroom attendants fits into the nightclub's overall organization of work.

\section{Job Description}

Bathroom attendants' roles are best understood when their duties divided into three categories; cleaning, security and tending to patrons. Cleaning involves keeping the bathrooms clean for the duration of their shits. This usually entails changing the garbage, cleaning vomit, and bodily fluids. They must also report necessary maintenance needs to management, supply stalls with toilet paper, and patrons with hand towels (either paper or cloth towels). Attendants set up a display area with a variety of products ${ }^{15}$ available to the patron in exchange of a tip. The selection of products vary based on the gender, age and economic status of the clientele. Perfumes,

\footnotetext{
${ }^{15}$ These products are purchased by the attendant for a detailed discussion see "Earning Uncertainty" in this analysis
} 
colognes, deodorant, gum, band-aids, condoms and hair products are amongst the most commonly used.

Bathroom attendants act as an extension of the security team in the nightclubs. It is often the task of the attendant who must inform patrons to leave their drinks at the door in regulation with provincial law, which prohibits alcohol in the bathrooms. It is also the responsibility of the bathroom attendants to ensure that only one patron enters each stall at a time. Limiting the number of patrons in one stall is intended to deter patrons from using the bathroom as a point of sale or consumption of drugs. In addition, attendants often draw 'bouncers' attention to patrons who might be too intoxicated to walk out of the club on their own. These patrons have been 'over served' which under the law implies the club has sold irresponsibly and could be subject to a fine (Ontario, 2009; Training for Servers-Smart Serve," 2010). In these cases security remove those patrons from the premise to avoid fines and tarnishing the image of the club.

Unofficially bathroom attendants find themselves performing a variety of tasks and activities in response to the unpredictability and the subculture of the nightclub in an effort to tend to the client. For example, in my experience working as a bathroom attendant, girls often used to come to the bathroom after having spilled drinks on their clothes. In these instances, I would not only supply Tide to Go (an instant stain remover] but would also apply the product. A female participant mentioned that she had sewn a bra strap that had ripped halfway through the night. The wardrobe malfunction and her clever solution earned her a $\$ 20.00$ dollar tip. Another bathroom attendant said that he/she often helps arrange safe rides home by calling taxies or providing friends of the patrons with directions to the club so they can get home safely. Attendants must be versatile and quick to react to opportunities that permit them to 
deliver what patrons consider exceptional service as a means to increase their odds of receiving a tip.

Almost all the participants reported an incident where patrons wished to use the bathroom for sexual encounters or drug use. Denying the request of the patron could translate into a confrontation with an intoxicated person, which is both emotionally distressing and potentially dangerous. In addition situations of this nature result in the attendant not receiving tips. Agreeing to allow patrons to miss-use the facilities also jeopardizes the bathroom attendants' job as they are failing to enforce the no liquor or a single person per stall rule. Deciding to agree to patrons' requests or not, is further complicated by what one participant referred to as "Money Rules". This simple rule states that in the club those with money have the power, and that power triumphs over all other regulations or rules. This explains why at times attendants are asked by security to ignore or bend the rules for some clients. However, figuring out who these 'powerful' individuals are is not always a straightforward process. In the case of a female participant, she refused to allow a man to enter the women's bathroom in her first week at work. After a short and loud confrontation with the man she found out he was the owner of the club. Fortunately for her, the owner did not retaliate or jeopardize her job. This example demonstrates the complexity and ambiguities that bathroom attendants experience when attempting to perform their job. What is expected of them is often ambiguous and dependent on several variables which must all be considered in a matter of seconds.

Although bathroom attendants are able to stop servicing customers shortly after the lights come on and the club closes at 2 am, their work is far from finished at this time. This is because attendants are responsible for washing the dirty hand towels that 
customers use during the night. The number of towels used during a shift varies on the volume of customers. It is common for attendants to run out of cloth towels during the night. In these cases they revert back to paper towels, however this usually has a negative impact on their tips. Participants in this study reported using anywhere from two hundred to six hundred towels a night. One participant uses 450 towels which he/she estimates is approximately " 50 kilos" when dry and " 100 Kilos" wet. Multiple trips up and down two flights of stairs are required to carry the towels and products in and out of the club during every shift. Washing the towels is done during their 'off time' and by using money from their earnings as they receive no subsidies or extra pay for washing the towels.

Table two lists some of the work tasks bathroom attendants perform during their shifts as well as work they take home. This table is constructed from the responses of participants in this study and should be treated as a first attempt in the documentation of the work that this position entails.

\section{TABLE 3: BATHROOM ATTENDANT RESPONSIBILITIES AND TASKS}

\begin{tabular}{|c|c|c|}
\hline Cleaning Tasks & Surveillance/ Security & Miscellanies \\
\hline $\begin{array}{l}\text { - Change garbage } \\
\text { - Sweep and Mop Floors } \\
\text { - Stock toilet paper } \\
\text { - } \text { Supply cloth or paper towels } \\
\text { - } \text { Plunge toillets } \\
\text { - Clean up vomit } \\
\text { - Pick up toilet paper from } \\
\text { - loor } \\
\text { - Clean mirrors } \\
\text { - Clean sink area }\end{array}$ & $\begin{array}{l}\text { - Ensure that no patron enters } \\
\text { the bathroom with alcohol } \\
\text { - Ensure that no smoking takes } \\
\text { place in bathrooms } \\
\text { - Ensure that no more than one } \\
\text { patron enters each stall } \\
\text { - Report to bouncers if patrons } \\
\text { are intoxicated } \\
\text { - Report fights or conflict to } \\
\text { security }\end{array}$ & $\begin{array}{l}\text { Take home and wash cloth } \\
\text { towels } \\
\text { Report needed maintenance } \\
\text { to management } \\
\text { Purchase and stock products } \\
\text { for customers } \\
\text { Tending and addressing the } \\
\text { needs of patrons }\end{array}$ \\
\hline
\end{tabular}




\section{Recruitment and Contracts}

In this analysis, the findings documenting contracts and work arrangements of bathroom attendants are limited by the biases of 'snowball sampling'. Because all participants were recruited through personal networks, they were all employed by the same person and consequently had similar work arrangements. For these reasons this study was unable to capture the diversity of contracts in the bathroom attendant business. On the other hand, the employer of all participants, who is also a bathroom attendant, also participated in this study. His participation was essential in shedding light on how recruitment and contracts operated in a three level hiring pyramid.

The business of bathroom attendants functions as a three-layer pyramid, at the top is the club owner or manager, followed by a recruiter, and at the bottom the bathroom attendant. The recruiter as the middle-man must approach the club manager offer the service in the bathroom and negotiate a price. The recruiter is also responsible for finding the attendants that will work in the bathroom and also negotiate a wage agreement with them. The wage of the bathroom attendant usually consists on just tips earned during their shift however some exceptions are made in order to compensate low tips, as it will be explained below ${ }^{16}$.

The recruiter who participated in this study described the business as highly competitive because although managers welcome the idea of a bathroom attendant. Part of the competitiveness is due to the lack of formal written contracts between the manager and the recruiter. This means that managers unsatisfied with their recruiter are able to simply dismiss them without any notice or justification". To maintain clients recruiters must offer a service that is different from other competitors by

${ }^{16}$ More information on wages, contracts and payments will be explained below. 
'professionalizing the position (Herod \& Aguiar, 2006). Through the use of cloth hand towels, uniforms and high quality products the recruiter is able to offer the manager what appears to be a more professional service, raising his ability to compete against others in the industry.

The manager of the club pays the recruiter a flat fee for the service of the bathroom attendant, this fee varies based on the number of bathrooms in the club, the number of days and hours that the service is needed. The contract between the manager and the recruiter is often verbal and payments predominantly (although not always) are in cash. Before agreeing on a price for the service of the attendants, recruiters ensure that the club will generate some income in tips by looking at the volume and socio-economic strata of the clientele. Another attendant referred to this same dynamic as the "quality versus quantity". Some clubs lack 'quality' meaning that the clientele might be young or from a low socio-economic strata, and therefore tip less. "Quantity" is also important as the number of patrons that visit the bathroom also increases tips although it also increases the work for the bathroom attendant. As the recruiter in this study explained some clubs are not worth servicing because they lack 'quality' and 'quantity' of patrons offering not opportunities to earn money.

The recruiter in this study, who is himself an immigrant and a bathroom attendant, finds through his personal network others who are willing to work. This recruiting strategy may help explain why there is a concentration of specific Latin American and Caribbean nationalities in the industry. The use of personal networks to recruit is a well documented feature of informal work (Carr \& Chen, 2002; Chen, 2004). In the case of this one particular recruiter, he provides attendants with a starting package consisting of cloth hand-towels, and some basic products for their display. Not 
all recruiters offer this package, when I worked as a bathroom attendant I was given three hundred towels that were all returned at the end of employment, but no products. It is of course in the interest of both the recruiter and the attendant that the display in the bathroom is well-stocked. With a well-stocked display, recruiters are able to deliver the professional service they offer to the managers and the attendant is able to increase their tips.

Earnings and wage arrangements between the attendant and the recruiter can be difficult to grasp because they are highly ambiguous and dependent on the specifics of the nightclub. A disproportionate amount of the money made in the bathrooms is made in the male's bathroom, because female attendants earn significantly fewer tips than male attendants. The earning gap varies by club but it can be as steep as three to one; where men may earn three dollars for every dollar women make. This difference in earnings can be attributed to a number of factors and thus needs to be further investigated. One of those factors is the under valuing of women's work in society. Historically, men's work has been constructed as important and as such men have been rewarded with higher wages even when the work performed is the same as women. The gender wage gap of bathroom attendants is proof that ideologically patrons continue to discriminate and underestimate the work of women. Unfortunately, gender wage gaps persist in places of work where government policies dictate equal pay as much as unregulated forms of work such as the one documented by this case study. Lower earnings have material and emotional consequences for the lives of female bathroom attendants. It limits their access to a variety of resources that could improve their lives. In addition, it emotionally breaks them down to see at the end of the night how their work has been deemed unimportant. 
"It is so upsetting to see how women don't value my work. They don't know all the sacrifices I have to do to be here. They don't stop to think about it...".

Knowing that clubs generate different revenue and that earning gaps between the sexes exist, the recruiter in this study creates incentives that appear to equalize the work division between men and women. For example women receive thirty dollars a night and are also excepted from washing towels, as the male attendant is responsible for taking them home and washing them. Sometimes thirty dollars wage is paid by the recruiter and sometimes by the male attendant out of his tip earnings for the night. Whoever pays this salary depends on how profitable the club is and how many bathrooms the club has. For example, in a club with one male and two female attendants, the recruiter will pay one of the females' hourly rate and the male attendant will pay the other. If this same club was highly profitable, then the recruiter may request that the male attendant pay both females; or alternatively if the club does not generate tips the recruiter would have to pay both female attendants.

The role of the recruiter needs to be explored further with a larger sample so that generalizations can be made about the precarity they experience. In the case of the recruiter who participated in this study, his work security was also uncertain because of the cash payments he received and the lack of written contracts. The industry was described by himself and other participants as quite competitive. This undermined the recruiters' ability to negotiate better payment for the service. Recruiters must also strive to reach a balance between what they receive from the manager and the wages they pay the bathroom attendants so that they too can make a profit.

In an effort to cut costs, recruiters prefer to employ female and male attendants (as a pair) such as a husband and wife. When couples work together and the club 
produces a significant amount of money, recruiters refrain from paying the woman. Hiring couples increases the profit for the recruiter but has significant consequences for the attendants and their families. Family dynamics, allocation of time and future plans within the family are disrupted by the late nights worked by the parents. One participant explained how difficult parenting became when you were working late nights even when it is only two or three nights a week, she had this to say;

"[the late nights] leave me with no energy. Saturday morning I'm a zombie but my children want our attention so we get up for them.."

This same mother is always afraid of leaving her teen-aged children at home during her shifts. A cell phone is her only way to check up on her children, she reports constantly looking at it to ensure that she does not miss any calls.

Another couple postponed getting pregnant for six months knowing that the summer months are amongst the most profitable in the club. For this couple, having their first baby was a well thought out decision that involved many months of planning and saving so that the mother could stay at home with the child after giving birth. The new arrangement of her staying home with the baby and the husband working late nights caused some strain on their personal relationship and the quality of time they spend as a family.

"I try to make sure the baby lets him [the husband] sleep, I help him get ready, I wash his towels but it is different, ... we are on different schedules".

It seems that it is easier to achieve a balance between partners when both work the same hours. However, when the family includes children most participants felt it was best for one parent to stay home. This, of course, is not an option for many of the participants who must work multiple jobs to sustain their families. 


\section{Indicators of Precarity for Bathroom Attendants}

The position of bathroom attendants displays all indicators of precarity as outlined by Canadian research. The following section focuses on how the indicators of precarity (as outlined in the first section of this thesis) are present in the working conditions of bathroom attendants in Toronto's nightclubs.

\section{Employment Certainty}

Employment certainty is defined as the employees' ability to access stable and continual work in addition to having access to social benefits and regulatory protection. This indicator is greatly shaped by the form of employment and the work contract. Contracts define the work period, number of hours as well as any social benefit available to the employee. In addition, contractual clauses also affect employee's eligibility for welfare services, pensions and protection under labour laws. (Vosko, 2006).

Bathroom attendants in this study displayed some of the lowest degrees of employment certainty because of their location in the informal sector. Informalization allows employers to operate outside of the legal regulatory framework, and to lower costs by lowering wages (Chen, 2004). Subcontracting and verbal agreements are the two predominant work arrangements that allow employers to access flexible labour and avoid their legal responsibility to the employee (Bauder, 2006; Chen, 2004; Sassen, 1994). Both of these contractual practices are present in the bathroom attendant business. The manager and recruiter have verbal agreements between them, and the recruiter receives cash payments, leaving no trace of their work relationship. In my study, the manager has subcontracted the bathroom attendant position to the recruiter 
and absolved the nightclub from any legal liability they might have towards the bathroom attendant. Meanwhile the club benefits from having vigilance in the bathrooms and from the services attendants offer to the clientele all for a fraction of what it would have cost to hire the attendant directly.

As for the employment arrangement between the recruiter and the bathroom attendant, none of the five ${ }^{17}$ participants in this study had signed a work contract outlining minimum pay or hours of work. Instead, work arrangements had been done verbally and with no written record. This of course makes bathroom attendants extremely vulnerable as the recruiter may abuse his power in a number of ways, including firing them, and the attendant would have no way of appealing this decision. In addition, bathroom attendants experience work uncertainty, which is residual from the instability of the nightclub business. One attendant experienced this uncertainty when the club where he worked was shutdown for weeks after a two-hour SWAT ${ }^{18}$ search. It is not uncommon for clubs to shutdown for renovations or license suspensions. In these scenarios, neither the manager of the club or the recruiter offers the bathroom attendant any pay or other work.

\section{Control Over the Labour Process}

Bathroom attendants' verbal contracts, absence of union membership and reliance on tips as primary earnings greatly reduces their control over labour process. Depending on the capacity of the nightclub, attendants might service up to three hundred patrons a night, many of whom make multiple trips to the bathroom. Because

17 five participants because the sixth participant was also their recruiter. 18 Special Weapons and Tactics Team 
attendants' primary (if not only) form of income comes from tips, turning away or not servicing patrons reduces their earnings. A dynamic that directly ties earnings to speed of production or service, as it exists in this type of work, creates pressures for the workers to push their bodies to high levels of strain and increases their chances at work injuries and poor health (A. Aguiar, 2006a; Lewchuk, et al., 2003). In the case of all participants, they reported feeling fatigued from their late night shifts to the point where they were unable to socialize, engage in activities with their families, or perform other daily tasks such as cooking.

The bathroom as a work location also has a direct impact on the quality of working conditions of bathroom attendants. The structural layout of the bathrooms, poor ventilation and exposure to loud music makes the bathroom a deprivable working environment. Bathroom in nightclubs are spaces built with neither the comfort of the attendant or the patron in mind. Instead, these spaces are intended to provide customers a momentary space to compose themselves so they can return to the primary space of consumption such as the bar. To discourage patrons from lingering in the bathroom, these spaces are poorly lit and offer no comfortable seating. Attendants wishing to take a break must bring their own chair, yet doing so is counter-productive for their tips.

"I have a chair but I don't use it because they [customer] think that because I sit I am not working".

Attendants must stand for their five-hour shift, with no breaks or place to escape the music and the constant stream of customers. Another significant issue is poor ventilation and air quality in the bathrooms, particularly during the summer months. Some nightclubs lower or turn off their air condition to encourage beverage 
consumption. Attendants are trapped in bathrooms with no windows, high temperatures and poor air ventilation because club management deemed their comfort and health disposable in order to ensure revenues through alcoholic consumption.

The natural urges and physical needs of bathroom attendants are also to be disregarded until the end of their shifts. Because they are not granted breaks they are unable to eat, drink or make use of the bathroom themselves. One participant laughed when she talked about the irony of working in the bathroom but not being able to use the bathroom. Attendants that leave their products unattended risk having products or money stolen from their tip jar.

"...I time it when I have to go to the bathroom [laughs] I take the best perfumes, my tip money and I go [into a stall] but I make sure it is during one of the popular songs so less girls will be in the bathroom".

Attendants unable to alter their work environments (bathrooms) or their working arrangements (contracts) are expected to adjust their service speed, suppress their bodily functions, and disregard their physical and emotional discomforts so they can maintain the club's image as a clean and modern space and in this way ensure some income for themselves and capital accumulation for the club owners.

\section{Schedule and Hours of Work}

Uncertainty surrounding scheduling and hours worked prevents bathroom attendants from having control over their time at work as well as their time off. Although for the most part attendants are assigned the same club every week because knowing the clientele increases tip revenue, they have little control over their schedules when extra events or parties they must work. Attendants are expected to be at the club, many times with just a few hours notice making it difficult to find a babysitter and 
reschedule plans. Attendants usually work from $9 \mathrm{pm}$ to $2 \mathrm{am}$, their working hours, and tasks leave them feeling "sluggish", "exhausted" and with little energy to do much. One attendant told me his social life had ended after he started this job.

"[E]veryone waits for the weekend to socialize but I work weekends... after I finish washing the towels [the day after a shift] I don't have time to go out... I also don't have energy".

Ironically, even though all participants identified the 'flexible' schedule as one of the primary reason why they engage in this type of work, the late hours were also resented as one of the hardest aspects of the job. One participant told me this was a "transitional job", a type of stepping- stone to something better. Working only two or three nights a week is an appealing idea for these immigrants as it allows them to find other day jobs, attend school, or volunteer, all strategies they hope will help them find better employment in Canada. Unfortunately, research shows that many of these strategies used by employees do not help them access better jobs (Goldring \& Landolt, 2009).

It is often hard for workers pursuing education or working other jobs to transition from one activity to the other without neglecting their health or meal preparations. One participant who worked at the club on Thursday nights found it incredibly difficult to wake up Friday morning to be at his other full time job. $\mathrm{He}$ reported having gained a significant amount of weight from the late nights and disrupted eating habits. In this way the schedule and working hours of bathroom attendants may have very real and intense effect on their health and quality of life. 


\section{Task Uncertainty}

The task uncertainty that bathroom attendants experience stems from lack of training, and ambiguous job descriptions. Training for the position consists of "shadowing" another attendant for approximately two shifts. After this period the attendant begins to work by him or herself. The training quality varies based on who the new attendants is shadowing, as "trainers" have not themselves received any instructions on how to train or what material to cover. All participants reported having different training experiences with emphasis on different aspects of the job. Most participants recalled being taught some "tricks" to improve their tips, and some suggestions as to what products are popular with which age groups. Because the new attendant receives training in a club different from what will become their regular place of work, often what they have learnt will not apply to their club:

"During [training] shifts I was never told to stop girls with drinks from entering the bathroom, maybe because that was a VIP bathroom, I don't know. But in my bathroom the security told me to stop them.... All bathrooms are different".

None of the attendants reported receiving training for handling cleaning solutions or directions on less strenuous ways of performing cleaning tasks. Four attendants worked in clubs where the cleaning and stocking duties were done by others so that they only did 'minor cleaning' during their shifts. 'Minor cleaning' was described as picking up pieces of toilet paper with cooking thongs, or cleaning the main counter, mopping around the sink if it is wet. While the other two participants did minor cleaning in addition to cleaning up vomit, plunging toilets, carrying heavy supply boxes and fixing leaky pipes. The difference in task completion makes this job uncertain as it affects the workers' ability to prepare and know what is expected them. 
Those attendants who stopped patrons from entering the bathroom with alcohol or reported to security when patrons were too intoxicated to get home safely, work as part of the security team in the club. Attendants in these positions run the same risks as security personnel, yet do not have the training or experience necessary to deal with difficult and potentially dangerous situations. They are also not economically compensated for their work as part of the security team, or have the opportunity to refuse any work that they might feel is unsafe. Refusing to perform specific tasks jeopardizes their access to future work both in the club and with their recruiter.

In general, bathroom attendants experience high levels of task uncertainty as their responsibilities are not clearly outlined in either verbal or written job description. They do not receive adequate training for the multiple tasks they perform and the little training they do receive is often irrelevant to their working environment. Finally, they lack any possibility to express hesitation or refuse to engage with work that they might feel is dangerous because their contracts offer no security.

\section{Earning Uncertainty}

Tips as the primary, or the only source of earnings for bathroom attendants significantly increases the precarity of their work and income. Tips are unpredictable. They vary based on the socio economic status of the clientele, the number of patrons, the night of the week, the season, and an array of other factors. Some nights, participants were able to make what they consider "good or decent" money. However, their earning precarity is still very high as nothing is guaranteed and they could walk away with next to nothing. One participant compared his job at the nightclub to gambling, as earnings were never for certain. To compensate for the risk in earnings 
most participants work a second job with a regular wage, and also rely on the earnings of others living with them to increase household economic stability. As part of the informal economy, the earnings of bathroom attendants are received in cash and undeclared. Consequently, no pay record exists to document or prove their employment. The absence of pay records makes it hard to dispute any employment rights in the eyes of the law. In other words, it jeopardizes their already limited state protection.

Tips not only affect (un)stable earnings and household income but, as it has been discussed, it shapes the organization of work and erodes the attendants' control over their work. Tips at a nightclub shape how much (if anything) bathroom attendants receive from the recruiter as a wage. It is in the best interest of the recruiter to ensure that attendants make money at the end of their shift. If tips are low he must economically compensate for their low earnings. If attendants repeatedly earn low tips and are not compensated, they will leave their jobs creating more work for the recruiter who is left to find and train another worker. Thus, the recruiter is always trying to ensure that attendants make money, at the lowest cost to him ${ }^{19}$. Attendants' need to take home earnings also pushes them to accept work conditions or perform tasks for customers that might be risky or harmful for their physical and emotional wellbeing. Attendants take home much less than their actual tips because of a variety of expenses necessary to make their work possible. As previously discussed, at the end of every shift male attendants take home towels for washing and drying. This task requires that they purchase laundry detergent and products in addition to paying for the washer and dryer as most of them prefer to wash in Laundromats to speed up the

${ }^{19}$ Note: all recruiters in the business that participants talked about were male. 
task. Two male attendants subcontracted the task of washing towels, one paid his wife and the other offered it to another female attendant who works with him at the same club. Regardless of who completes this task, it reduces the net income of attendants at the end of the night.

Transportation and parking fees also reduce the earnings to bathroom attendants. Parking in Toronto's entertainment district during a weekend ranges from $\$ 15.00$ to $\$ 30.00$ dollars a night. Access to a vehicle is a must for attendants, as the weight and size of the towels and products limits them from taking public transportation. Also a car is essential because attendants complete work past 2 am when the Toronto Transportation Commission offers infrequent service on limited routes only. Attendants without vehicles spend a significant amount of time and effort finding rides home.

The products that attendants display and rely on to increase their tips are all purchased with money earned in the bathroom. Colognes and perfumes are amongst the most costly and sought out products in the bathroom, their prices range from fifty to one hundred dollars depending on the brand. On average, attendants have two or three prestigious colognes/ perfumes and three or four less pricey products which usually lasts anywhere from seven months to a year. They offer gum, mints, and a variety of smaller products that need to be replenished more frequency. It is hard to calculate the total value of their product kits as they are put together over time, yet one attendant estimates that his products cost $\$ 400.00$. This same attendant told me it was very much like "investing" in his own business because without these products earning tips was harder. The notion of the bathroom attendant as an entrepreneur is problematic as it masks the real time and money they spend washing towels, purchasing products, and 
transporting themselves. They see all those tasks as necessities to meet the needs of their 'business', so they absorb the extra cost and time without giving it a market value. The notion that they benefit the most from 'investing' in their 'business' invisibilizes and legitimizes their self-exploitation because it prevents attendants from questioning their work arrangements.

\section{Regulatory Protection}

Regulatory protection refers to protecting working conditions and the standard of living of workers through law and labour policy. Traditionally this has been achieved through the regulatory presence of unions or labour law (Vosko, 2006). In the case of bathroom attendants, no union exists and their coverage under provincial and federal labour laws is also limited. The limitations of the law does not only depend on whether those laws exist or not, but also on how effectively they are enforced. Vosko states that a broader definition of effectiveness of regulatory protection looks at "...legal coverage, awareness of coverage, legal design, policies on application and enforcement, employer avoidance, and disparities of power and inequalities between groups of workers" (2000, p. 30). According to this definition, bathroom attendants experience high levels of regulatory failure.

As part of the informal sector and with only a verbal contract, bathroom attendants' coverage under legislation is ambiguous at best. Are bathroom attendants self-employed? Are they employees of the recruiter or the nightclub? The lack of clarity regarding the nature of their work and status as workers not only places a challenge to an understanding of their rights, but it also poses some limitations on their ability to make claims in the eyes of the law. For example self-employed workers are excluded 
from parts of legislation (Bernstein, Lippel, Tucker, \& Vosko, 2006). Thus, it is the exclusion of self employed workers from regulatory protection that creates the incentive for club owner to subcontract the position of bathroom attendant. Cash payments or undeclared earnings also limit employees from qualifying for programs such as Employment Insurance (Bernstein, et al., 2006; Shields, 2004). Many employees in the informal sector find themselves in some sort of legislative limbo. Their rights have not been denied, or excluded yet no legislation applies to their situations (Bernstein, et al., 2006, p. 212).

Immigrant status as a social location also influences bathroom attendants' access to regulatory protection. Their status as newcomers limits their understanding of procedures, regulation and their rights as employees. When participants were asked if they understood their rights under Ontario's labour laws five out of the $\operatorname{six}^{20}$ employees displayed hesitation and admitted not really knowing much about the topic. One participant followed his response by telling me that he is aware of being exploited and that his working conditions are not the best, yet he "accepts" this because he knows that he is not declaring tips. This participant's labour market position in the informal sector has led him to believe that he has no rights under the law. Some newcomers also experience unwillingness to interact with any part of the legal system or government agency as a way to reduce their visibility in their new country (Bernstein, et al., 2006, p. 215).

\section{PROPERTY OF \\ RYERSON UNIVERSTYY LIBRART}

${ }^{20}$ The sixth participant was not asked this question thus his response is not included. 


\section{TABLE 4: INDICATORS OF PRECARITY FOR BATHROOM ATTENDANTS IN TORONTO'S NIGHTCLUBS}

\begin{tabular}{|c|c|}
\hline $\begin{array}{l}\text { EMPLOYMENT } \\
\text { CERTAINTY }\end{array}$ & $\begin{array}{l}\text { Availability of future work not guaranteed, } \\
\text { - Verbal contracts-means that they can be fired at any time without notice }\end{array}$ \\
\hline $\begin{array}{l}\text { CONTROL } \\
\text { OVER LABOUR } \\
\text { PROCESS }\end{array}$ & $\begin{array}{l}\text { - Little control over speed of service and number of customers } \\
\text { - No breaks during their shift, not able to sit } \\
\text { - } \quad \text { Shork environment poorly ventilated, possibly dangerous and unhealthy } \\
\text { - No control over hours worked } \\
\text { - Working late at night and then take work home (washing towels) } \\
\text { - } \quad \text { Ambinimal time to rest between shifts and other jobs } \\
\text { Lack of training for the multiple tasks they perform }\end{array}$ \\
\hline $\begin{array}{l}\text { EARNING } \\
\text { CERTAINTY }\end{array}$ & $\begin{array}{l}\text { - Absence of written pay records } \\
\text { - } \quad \text { Uncertainty of earnings as primary earnings come from tips } \\
\text { - No hourly wage for male attendants. } \\
\text { - Female attendants receive less than minimum wage of } \$ 10.000 / \mathrm{hr} \text { in } \\
\text { Ontario. }\end{array}$ \\
\hline $\begin{array}{l}\text { REGULATORY } \\
\text { PROTECTION } \\
\text { AND CONTROL }\end{array}$ & $\begin{array}{l}\text { - } \\
\text { - } \\
\text { Ambiguous coverage by provincial employment laws } \\
\text { No social wage- no extended dental, medical benefits, no pension, do } \\
\text { disability or lie insurance }\end{array}$ \\
\hline
\end{tabular}




\section{The Costs of Emotional Labour}

"Some nights I just want to quit. I think 'this is enough'. I want to throw the towels and run out, but then I calm myself and I think of positive things, I think of my daughter."

"Emotional labour", a term coined by Hochschild in the 1980 s defines it as work that requires the manipulation of emotions and behaviors to produce the correct response in the client. Emotional labour is related to the commercialization of human feelings. The consumption experience expands beyond products and it includes the worker's identity (Chong, 2009; Hochschild, 1985). However, how workers perform emotional labour is dependent on their social location, as society has different behavioral expectations dependent on one's race, gender, and migration status (Chong, 2009). The work of bathroom attendants as part of the nightclub experience and faceto-face customer service involves emotional labour. Unfortunately, the emotional labour of bathroom attendants comes with a high price as it reinforces the social hierarchies that subordinates them, and takes its toll on their emotional wellbeing.

The work of bathroom attendants involves emotional labour, as it requires the constant manipulation of their emotions to create the fantasy of servitude consumed by the patron. The service in the bathroom creates a hierarchy where the 'patron' is pampered and made to feel superior to the 'servant', in this case the bathroom attendant. Attendants must always perform their role with a smile, be helpful and appear to be working. A successful performance is rewarded with a tip. Thus what the customer consumes in the bathroom is not simply a mint and the spray of the latest cologne but also the interaction that promote their feelings of superiority.

The quality of products bathroom attendants display becomes reflective of the class and superiority of the club and of the clients that consume them. Attendants 
display expensive perfumes and colognes to tempt customers to use the service because after use clients feel obliged to leave a tip. Thus the products function as bait enticing patrons to consume because of the perceived value society has assigned to those products and the people that use them. Use of the products are usually followed by tipping because it marks the completion of the transaction by assuring customers that they have successfully performed their roles as 'patrons'. This symbolic interaction and consumption practice "...doesn't merely reflect a person's social position but actively and actually generates it" (Lewis, 2002, p. 268). In this case, reaffirming patrons' social position demands the social subordination of the bathroom attendant.

Bathroom attendants are not passive actors. They perform their roles with a smile and seek cleaver ways to entice consumption. One attendant has learnt to recognize the smell of colognes so he is able to offer patrons a spray of the right cologne when they are in the bathroom. Others will remove paper towels from dispensers so patrons will have to use the cloth towels. All these tactics may be seen as opportunistic by some, but engaging in them is in fact extremely demoralizing for the bathroom attendant. Attendants understand that without the products and the towels their work is not valuable to the patron, and therefore that it would not be compensated economically. They rely on those tactics and their ability to perform the subordinate role as ways to support their families because they are unable to find decent employment.

Unfortunately, performing as bathroom attendants reinforces and normalizes the racial, ethnic hierarchies that have undoubtedly pushed these workers to the margins. Immigrants' presence in dangerous, dirty and difficult jobs has been normalized by the neoliberal notion that labour market failure is a result of individual 
capabilities and not structural ones (L. Aguiar, 2006). Thus having an immigrant in the bathroom allows patrons to engage in the consumption of the attendant's identity and the production of theirs with no disruptions.

As I previously mentioned, when I worked as a bathroom attendant I was in my early twenties and had lived in Canada for over 12 years. I was attending university and had accumulated what Bourdieu refers to as 'symbolic capital". This form of capital expands beyond income or markers of class, to cultural demarcations and consumption practices that define an individual within a group (Lewis, 2002, p.268). In many instances, my ability to speak English fluently, or the fact that I was pursuing post secondary education was received with disbelief and followed by questions seeking to understand why I worked in this job. In one occasion, a woman asked if I was a single mother or if 1 lived alone in Canada. An affirmative response to either question would have sufficed in explaining why someone with my cultural capital would be working in the bathroom. It was clear from her reaction that I had disrupted her understanding of social hierarchies and interrupted her ability to consume and perform her role of patron in the bathroom.

In addition to reproducing social, racial or ethnic hierarchies, the work of bathroom attendants has very real effects on their emotional well being. For bathroom attendants it is difficult to combat negative emotions resulting from exchanges with customers because they experience them repetitively throughout their shifts. When attendants do no receive tips their work is regarded as worthless, yet often, receiving a tip given by pity is just as demoralizing. In both instances the attendant is stripped of their pride and deemed inferior. 


\section{Tactics of Resistance}

When I decided to leave my job as a bathroom attendant I did so because the late nights had taken their toll on my physical wellbeing. More importantly, however, I thought that the emotional decay I felt was not worth the flexibility or the money that the job offered. I was fortunate to be able to make this decision knowing that I would be able to find another job with some ease. This, however, is not the case with many of the people who participated in this study. Some of them have children and extended family, here in Canada or back in their countries of birth, that depend on them economically. Others continue to work as bathroom attendants hoping that the choices and sacrifices they make today will provide new opportunities in the future. Until that day comes, they continue to work taking refuge in the small tactics that help them contest their powerlessness.

Some participants opened up about their emotional discomfort and in doing so revealed some of the thoughts or actions that give them some relief and keep them going. For many attendants their earnings were the main reason they continued to do this job. During very difficult or exhausting nights one woman admitted to counting her tip money numerous times during her shift, as a way to remind herself of why she was there. One wife shared that she felt reassured by the fact that her husband was working in the room next to hers. At the end of their shift they supported each other emotionally.

"We tell each other how our night was; the funny things and the bad things... but we just let it out so it doesn't go home with us ...because we try to make it go away before we get home".

Another attendant quite comically lied about his nationality or his ability to speak English to avoid interaction with customers. He provided the service with a smile but 
when he suspected that the patron might ask questions or engage in personal conversations he prevented it by simply telling them he does not speak English well.

To many, the strategies I have described below can be considered weak tools of resistance because they do not directly challenge the structures or ideologies which subordinate bathroom attendants. They also do not improve their working conditions or the invisibility they experience. Bathroom attendants' agency is compromised by their lack of social power, rendering them captive of their situations. These actions, as small as they might seem, are their only way of fighting back feeling of inferiority and discrimination. 


\section{Conclusion}

As stated in the introduction, this analysis aimed to explore the interlocking structural and ideological conditions that push immigrants into precarious work. This overarching objective has provided the thematic connection between the literature review and the case study. It has also dictated the use new political economy as the theoretical framework. This theory is best able to capture and analyze the structures and realities within the political, economical and social realm that subordinate immigrants to precarious work. At its core this study clarifies some of the factors leading to immigrant's over-representation in precarious work by taking an in depth look at bathroom attendants in Toronto's nightclubs.

Grounded in multiple bodies of literature, this analysis relies heavily on Canadian research dealing with precarious work. The literature review introduces employment certainty, control over labour process, earning certainty and regulatory protection as the four indicators of precarity. Using these four predictors as analytical tools, the case study demonstrates that the working conditions of bathroom attendants display high levels of precariousness in all four categories.

The high precarity of the work of bathroom attendants translates into vulnerable workers and families who are emotionally and physically exhausted. Unfortunately the consequences of working in the bathroom as reported by participants in my study confirm the findings reported in the literature. The effects of this job have too many negative manifestations on the everyday lives of these immigrants. Amongst the most alarming consequence is their deteriorating health; detachment from friends and family because of irregular working hours and conflicting schedules; and low selfesteem from interactions with customers. 
To improve the work conditions of these workers would require a conscious effort to tackle all four indicators, as working on just one would not necessarily improve their work experience. This research concludes that tips as the primary or only source of income has acute consequences on the precarity of the attendant. Tips negatively affect all four indicators. For attendants to earn tips, they must introduce products and cloth towels to their service. These two additions costs them money and extends their working hours. Tips also pressure attendants to force their bodies to work harder and faster to service more clients, taking away their control over their work. Finally, because earnings are not declared and no pay record exists it also limits their ability to make claims in the eyes of the law. Thus it appears that if their dependency on tips could be reduced, attendants would benefit from an improvement in all four indicators of precarity explored by this analysis.

\section{Areas for Further Research}

I conclude this analysis with a reminder that the position of bathroom attendants and the industry itself needs to be explored further in the literature. As previously mentioned, the sample size and "snowball sampling" posed some limitations on the findings of this research particularly when looking at contracts and work arrangements. Research into a wider variety of contracts and work arrangements would be very important as these variables have a direct impact on the levels of precarity experiences by bathroom attendants. What follows is a brief discussion of ideas and suggestions for further research.

A study with a larger sample is critical in order to document the diversity of contracts and work arrangements that exist in the bathroom attendant business. During 
my research, participants shared stories of recruiters who demand a percentage of bathroom attendants' tips. They also described work arrangements that exclude the recruiter, where the bathroom attendant directly deals with the manager of the club. Thus, the organization of work described in this study appears to be the most common contract pattern in the industry, but not the only one. This is why it is critical to document other possible arrangements and define the level of precarity experienced by those workers.

Recruiters' own vulnerabilities in a competitive sector or their capacity to exploit other workers was not explored in enough detail in this study. Limited by the participation of only one recruiter and due to some hesitation on his part to share detailed information about payment arrangements and contracts with the nightclub, it was difficult to gage to what degree his position as a recruiter helps him improve his work conditions.

Performing as bathroom attendants affects women and man differently with women experiencing higher levels of precarity. There is clearly a gendered dimension to this job that needs to be looked at with more precision. This study touched on a couple of factors that exposed how the industry and the work itself are gendered. The most evident is the significant earning gap between male and female attendants even when the earnings come from tips. Women's earnings at times can be as low as one third of men's, which has drastic consequences on their standard of living. Women also appear to be allocated to bathrooms that offer lower tip predictability. One participant explained that VIP bathrooms usually consist of one or two very private stalls. Attendants don't make money from the volume of patrons as only a limited number use those bathrooms. Instead, tips are expected to be higher because the clientele has a 
higher socioeconomic status. The VIP bathroom is usually serviced by a woman, thus women are assigned to the bathrooms that offer the least earning predictability.

Latin Americans and Caribbean immigrants are over represented in the bathroom attendant position. One participant shared his own views on the racial hierarchies that exist in the industry. He feels that Latin Americans' racial hybridity and lighter skin provide them with an advantage over Caribbean bathroom attendants. Managers choose to do business with Latin American recruiters knowing that they will recruit from their personal network and within their ethnic group. According to this participant, Latin Americans service more lucrative nightclubs that cater to the needs of a 'whiter' clientele. Unfortunately, this research was unable to explore the racial dimensions of the work and income that this participant exposed because all participants were Latin American. Given the characteristics of my sample, a comparative study which could capture how race regulates and obstructs access to work and earnings in this industry was impossible. Modifying the sample size and recruiting strategy would help capture the racial dimension for future research.

This study concludes that bathroom attendants experience three important layers of precarit: First, precarity from their presence in the informal sector of the economy; second, precarity from the industry where they work and the tasks they must perform during their shifts; And third, precarity as a result of their social location, which includes their status as immigrants, their race and gender. The combination of these three layers of precarity makes bathroom attendants one of the most vulnerable group of workers in the labour market. Attendants' precarity and social exclusion has silenced their voices and created barriers preventing them from mobilizing. Thus, it appears that to improve their working and living conditions it is vital for scholars, 
activist, and policy makers to promote relevant and accurate research that can help generate appropriate changes. 


\section{Works Cited}

Aguiar, A. (2006a). Introduction: Cleaners and the Dirty Work of Neoliberalism. Antipode, 38(3).

Aguiar, A. (2006b). Introduction: Ethnographies of the Cleaning Body. Antipode, 38(3).

Aguiar, L. (2006). Janitors and Sweatshop Citizenship in Canada. Antipode, 38(3), 440461.

Arat-Koc, S. (1999). Neo-Liberalism, State Restructuring and Immigration: Changes in Canadian Policies in the 1990s. Journal of Canadian Studies, 34(2).

Bauder, H. (2006). Labor Movement : How Migration Regulates Labor Markets. New York: Oxford University Press.

Bernstein, S., Lippel, K., Tucker, E., \& Vosko, L. (2006). Precarious Employment and the Law's Flaws: Identifying Regulatory Failure and Securing Effective Protection for Workers. Precarious Employment: Understanding labour market insecurity in Canada, 203.

Broad, D. (2000). Hollow Work, Hollow Society? : Globalization and the Casual Labour Problem in Canada. Halifax, N.S.: Fernwood Pub.

Carr, M., \& Chen, M. (2002). Globalization and the Informal Economy: how Global Trade and Investment Impact on the Working Poor: Working Paper on the Informal Economy, Employment Sector.

Cervenan, A. (2009). Service Class Prosperity in Ontario Retrieved from http://martinprosperity.org/research-and-publications

Chen, M. (2004). Rethinking the Informal Economy: Linkages with the Formal Economy and the Formal Regulatory Environment.

Chong, P. (2009). Servitude With a Smile: A Re-Examination of Emotional Labour Just Labour: A Canadian Journal of Work and Society, 14.

Collins, J. L., \& Gimenez, M. (1990). Work without wages : comparative studies of domestic labor and self-employment. Albany: State University of New York Press.

Cranford, J., \& Vosko, L. (2006). Conceptualizing Precarious Employment: Mapping Wage Work Across Social Location and Occupational Context. Precarious Employment: Understanding labour market insecurity in Canada.

Das Gupta, T. (1996). Racism and Paid Work. Toronto: Garamond Press.

de Wolff, A. (2006). 'Privatizing Public Employment Assistance and Precarious Employment in Toronto. Precarious Employment: Understanding labour market insecurity in Canada, 182-199. 
Del Balso, M., \& Lewis, A. D. (2005). First Steps A Guide to Social Research (Third ed.). Toronto: Thomson Nelson.

Evans, J., \& Gibb, E. (2009). Moving From Precarious Employment to Decent Work GURN: the global union research network, 13.

Florida, R. L. [2002). The Rise of the Creative Class : and How It's Transforming Work, Leisure, Community and Everyday Life. New York, NY: Basic Books.

Fudge, J. (2003). Labour Protection for Self-Employed Workers. Just Labour, 3, 41.

Galabuzi, G. (2005). Factors Affecting the Social Economic Status of Canadian Immigrants in the New Millennium. Canadian Issues, 53-57.

Galabuzi, G. (2006). Canada's Economic Apartheid: the Social Exclusion of Racialized Groups in the New Century: Canadian Scholars Press.

Goldring, L., Berinstein, C., \& Bernhard, J. (2007). Institutionalizing Precarious Immigration Status in Canada. Early Childhood Education Publications and Research, 4.

Goldring, L., \& Landolt, P. (2009). Immigration and Precarious Employment in the New Economy (Introduction to Research and Briefts), from http://www.arts.yorku.ca/research/ine/public outreach/materials.html

Harvey, D. (2000). Spaces of hope. Berkeley: University of California Press.

Herod, A., \& Aguiar, L. (2006). Introduction: Geographies of Neoliberalism. Antipode, $38(3), 435$.

Hochschild, A. (1985). The Managed Heart: Commercialization of Human Feeling. Symbolic interaction, $8(2)$.

Kelly, P., \& Lemoine, M. (2010). TIEDI Labour Force Update Toronto Immigrant Employment Data Initiative.

King, K. M. ( 2009). The Geography of Immigration in Canada: Settlement, Education, Labour Activity and Occupation Profiles Retrieved from http://martinprosperity.org/research-and-publications

Kipfer, S., \& Keil, R. (2002). Toronto Inc? Planning the Competitive City in the New Toronto. Antipode, 34(2), 227-264.

Lewchuk, W., de Wolff, A., King, A., \& Polanyi, M. (2003). From Job Strain to Employment Strain: Health Effects of Precarious Employment. Just Labour, 3, 23-35. 
Lewchuk, W., Wolff, A., King, A., \& Polanyi, M. (2006). The Hidden Costs of Precarious Employment: Health and the Employment Relationship. Precarious employment. Understanding Labour Market Insecurity in Canada, 141-161.

Ontario, S. (2009). Liquor Licence Act. E-Laws, from http://www.elaws.gov.on.ca/html/statutes/english/elaws statutes 90119 e.htm

Peck, J. (2005). Struggling With the Creative Class. International Journal of Urban and Regional Research, 29(4), 740-770.

Pennington, S. ( 2009). The Opportunity for Entrepreneurship in Ontario: An Analysis of Self-Employment across City-Regions. Retrieved from http://martinprosperity.org/research-and-publications

Purcell, J., \& Graham, K. (2005). Typology of Toronto Nightclubs at the Turn of the Millennium, A. Contemp. Drug Probs., 32, 131.

Sassen (1994). The Informal Economy: Between new Developments and Old Regulations. Yale Law Journal, 103(8).

Sassen (2006). Cities in a World Economy (3rd ed.). Thousand Oaks, Calif.: Pine Forge Press.

Sayer, S. (2001). Issues in New Political Economy. Oxford: Blackwell.

Shields, J. (2004). No Safe Haven: Markets, Welfare, and Migrants. Philip Kretsendemas and.

Stevens, E. (1973). Marianismo: The Other Face of Machismo in Latin America. Female and male in Latin America: essays, 89-102.

Teelucksingh, C., \& Galabuzi, G. (2007). Working Precariously: The Impact of Race and Immigrant Status on Employment Opportunities and Outcomes in Canada. Race and Racialization: Essential Readings, 202.

Training for Servers-Smart Serve (2010). 2010, from http://www.agco.on.ca/en/whatwedo/training smartserve.aspx

Verma, A. ( 2009). Low Wage Service Workers: A Profile. Retrieved from http://martinprosperity.org/research-and-publications

Vosko, L. (2000). Temporary Work: The Gendered Rise of Precarious Employment Relationship. Toronto: University of Toronto Press.

Vosko, L. (2003). Precarious Employment in Canada: Taking Stock, Taking Action. Just Labour, 3, 1-5.

Vosko, L. (2006). Precarious Employment : Understanding Labour Market Insecurity in Canada. Montreal: McGill-Queen's University Press. 
Walters, D., Phythian, K., \& Anisef, P. (2006). Understanding the Economic Integration of Immigrants: A Wage Decomposition of the Earnings Disparities Between NativeBorn Canadians and Immigrants of Recent Cohorts. CERIS Working PaperN ${ }^{\circ}, 42$.

Whyte, M. (2009, June 27, 2009). Why Richard Florida's Honeymoon is Over. The Toronto Star, from http://www,thestar.com/article/656837 


\section{Appendix}

Appendix A: Interview Questions

1) When did you first come to Canada?

2) Did you work and if so what did you do before coming to Canada?

3) When did you start working as a bathroom attendant?

Prompt: how did you hear about this job?

4) What is your work arrangement like between you and your boss? Prompt: Have you signed a contract?

Prompt: Do you know how the law protects you when you are at work?

5) How long have you been working as a bathroom attendant?

Prompt: How many shifts a week do you do?

Prompt: How long are your shifts?

6) Please describe what are your responsibilities as a bathroom attendant? Prompt: What sort of things do you clean?

Prompt: Did you receive any training for this job?

7) Do you have other jobs or do what other activities do you do during the week?

Prompt: do you attend school or volunteer?

8) Do you like or dislike your job as a bathroom attendant? And why? Prompt: what are some (if any) of the benefits for this job?

Prompt: what are some of the negative aspects of the job?

9) How has your work as a bathroom attendant affected your life?

Prompt: has it affected your health or personal life in any way?

10) Have you experienced racism or discrimination while working? Prompt: How did you deal with it?

11) Is there anything else you would like to share before we conclude our interview?

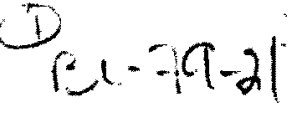

